\title{
Oceňování dřevostaveb v kontextu tržního oceňování
}

\author{
Tomáš Hrdlička* ${ }^{*}$ Tereza Jandásková \\ Vysoké učeni technické v Brně, Ústav soudniho inženýrstvi
}

Valuation of Wooden Houses in the Context of Market Valuation

\begin{abstract}
Abstrakt
Problematika oceňování dřevostaveb je ve znalecké praxi čím dál tím více diskutovanějšíi, také vzhledem $\mathrm{k}$ tomu, že se výstavba dřevostaveb rok od roku zvyšuje. Článek obsahuje přehled jednotlivých konstrukčních systémů především se zaměřením na různé technologie výstavby S problematikou ocenění dřevostavby rodinného domu se znalec/odhadce může setkat v různých fázích životního cyklu této stavby. Proto se článek zaměřuje na využití různých metod ocenění $\mathrm{v}$ předinvestiční a provozni fázi životního cyklu stavby. Dále se článek zabývá pořizovacími náklady dřevostaveb v závislosti na použité technologii a zároveň přináší doporučení, jakým způsobem reflektovat tyto rozdíly do stanovení tržní hodnoty resp. ceny obvyklé.
\end{abstract}

Klíčová slova: dřevostavby, oceňování, nákladové ocenění, tržní hodnota, roubené stavby.

\section{1. ÚVOD}

Podíl dřevostaveb na celkové výstavbě rodinných domů v České republice roste. Tento trend potvrzují počty dokončených dřevostaveb $\mathrm{v}$ minulých letech. Zatímco $\mathrm{v}$ roce $\mathrm{v}$ roce 2000 byl podíl dřevostaveb na celkové výstavbě rodinných domů $1,4 \%$ a dokončeno bylo 133 rodinných domů na bázi dřeva, v roce 2018 se jednalo o 2945 rodinných domů, což činí podíl 16,1\% na celkové výstavbě rodinných domů v České republice. [1]

Z výše uvedeného je patrné, že výstava dřevostaveb v České republice nabývá obliby. S novou výstavbou je však spojena také potřeba zjišt’ování tržní hodnoty, resp. obvyklé ceny takových domů. Lze tedy předpokládat, že znalci a odhadci se budou do budoucna mnohem častěji setkávat $\mathrm{s}$ oceněním těchto typů staveb a s problémy, které při jejich ocenění nastanou.

\begin{abstract}
The issue of valuation of wooden houses in expert practice is possible further by being more discussed. The number of wooden buildings increases every year. The article contains an overview of different construction systems of wooden houses.The market value needs to be determined in various phases of the construction life cycle. The article focuses on the use of different valuation approaches in the pre-investment and operating phases of construction life cycle. Furthermore, the article deals with the investment costs of wooden houses depending on the construction system. Also recommendation on how to reflect differences of construction systems to market value is included.
\end{abstract}

Keywords: wooden houses, valuation, cost valuation, market value, timber houses.

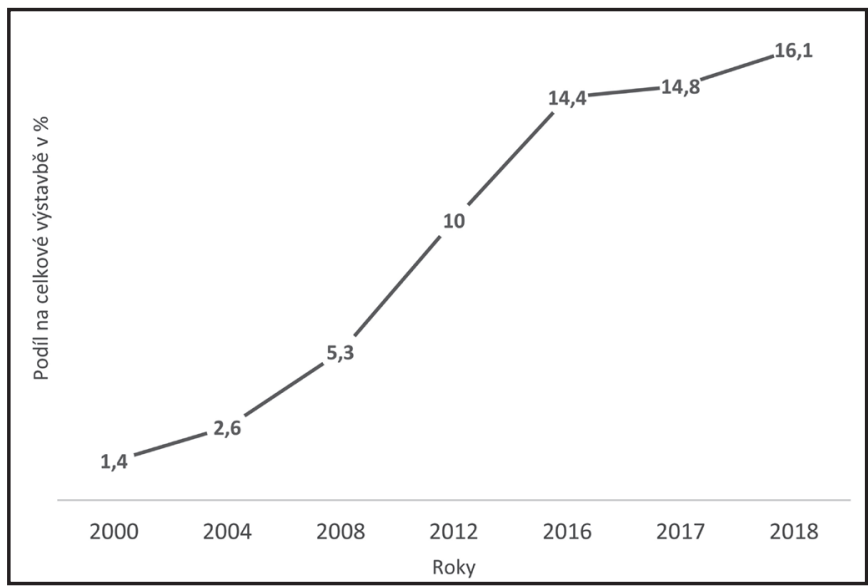

Obr. 1 Vývoj podílu dřevostaveb na celkové výstavbě rodinných domů v letech 2000-2018 [1].

Fig. 1 Development of the share of wooden houses in the total construction of family houses in 2000-2018 [1]. 


\section{KONSTRUKČNÍ SYSTÉMY DŘEVOSTAVEB}

V současných tuzemských právních předpisech není pojem dřevostavba nebo stavba na bázi dřeva přesně definován. Pro účely následujícího textu je význam pojmu ,dřrevostavba” převzatý z odborné literatury: „Pojmem drevostavba rozumíme takovou stavbu, která pro svou nosnou konstrukci, zajištujicí prenos zatiženi a celkovou prostorovou tuhost a integritu, využivá v prevážné miře dřevo a materiály na jeho bázi“. [2]

$\mathrm{Z}$ hlediska druhu konstrukce dřevostavby lze rozlišovat několik typů dřevostaveb, které lze dále kategorizovat dle podílu použitého dřeva. Právě charakter konstrukce má přímý dopad na pořizovací náklady.

\subsection{Konstrukce $\mathrm{z}$ masivního dřeva}

- Sruby a roubenky lze charakterizovat ,jako stěnu postavenou z vodorovně umistěných masivnich dřevěných prvků v různém stupni opracováni - od jen nahrubo oloupaných kmenů, kuláčù (povali̊), přes dvoustranně opracované ("omitané"), trámce nebo fošny, ze všech čtyr stran opracované trámce." [3] V př́ípadě použití hrubě opracované kulatiny se častěji využívá označení srub.

U staveb, kde jsou tvořeny stěny $\mathrm{z}$ masivního dřeva jako jediné vrstvy, tedy sruby a roubenky, je v současné době problém splnit základní požadavky na konstrukce v duchu vyhlášky č. 268/2009 Sb., o technických požadavcích na výstavbu, ve znění pozdějších předpisů [4], stejně jako požadavky uvedené ve vyhlášce č. 78/2013 Sb., o energetické náročnosti budov, ve znění pozdějších předpisů. [5] Jedná se o požadavky na součinitel prostupu tepla na úrovni požadované hodnoty, tedy $0,30 \mathrm{~W} /\left(\mathrm{m}^{2} \cdot \mathrm{K}\right)$, respektive 0,7 násobek požadované hodnoty.

Řešením je například využití sendvičové konstrukce s vloženou tepelnou izolací mezi dvě vrstvy masivní stěny.
- CLT panely (cross-laminated timber - kř́žem lepené řezivo) patři k nejnovějším technologiím výstavby v oblasti dřevostaveb. Dřevěné panely v obvyklé tloušt'ce $80-100$ mm se doplňují kontaktním nebo nekontaktním zateplovacím systémem. Masivní dřevěná stěna zajišt’uje přenos zatížení a stabilitu stavby. Dřevěné panely je také možné nechat jako pohledové. [6] Technologie výstavby je velmi podobná s výstavbou železobetonových panelových staveb

\subsection{Rámové dřevostavby}

Charakteristickým prvkem je nosný dřevěný sloup na výšku jednoho podlaží. Dřevěný rám je zpravidla doplněn dřevěným plošným materiálem (OSB deska, překližka), který zajišt’uje tuhost konstrukce. Prostor mezi sloupky je vyplněn tepelnou izolací a dále je skladba doplněna o kontaktní či nekontaktní zateplovací systém. Na interiérové straně je následně instalována parozábrana či parobrzda a interiérová úprava stěn, nejčastěji v podobě sádrokartonové předstěny. Dle stupně prefabrikace lze rozlišovat jednotlivé technologické postupy:

- staveništní (letmá) montáž, kdy jednotlivé prvky jsou montovány př́mo na stavbě,

- plošná prefabrikace (stěnové panely) patří k nejrychlejším způsobem výstavby. Panely mohou mít různé stupně dokončení - např́klad pouze dřevěný rám s opláštěným nebo kompletní skladba stěny bez povrchové úpravy. [7]

Z hlediska prostupu vodních par konstrukcí lze rozlišovat konstrukce difúzně otevřené a difúzně uzavřené. Pro doplňkovou tepelnou izolaci difúzně uzavřených konstrukcí je zpravidla použit polystyren, který patří k nejlevnějším izolantům. Naopak difúzně otevřené konstrukce vyžadují použití materiálů propustných pro vodní páru, např́íklad tuhé minerální vlny, dřevovláknité desky aj.

Dřevostavby mají určité odlišnosti oproti zděné výstavbě, které

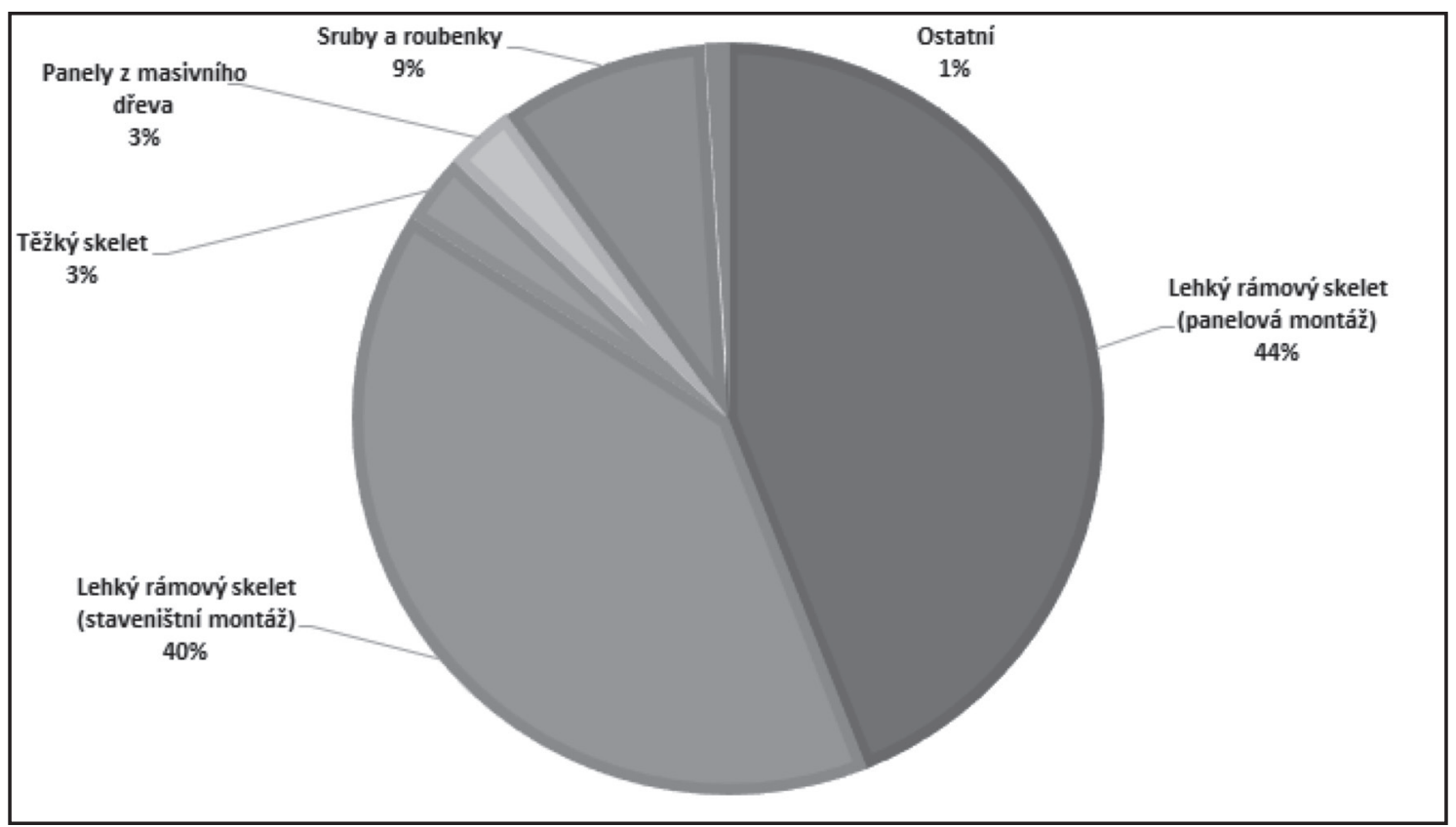

Obr. 2 Výstavba dřevostaveb v roce 2018 dle technologie [1]

Fig. 2 Construction of wooden houses in 2018 according to technology [1]. 
je při určování tržní hodnoty stavby v různých fází jejího životního cyklu reflektovat.

\section{ODLIŠNOSTI DŘEVOSTAVEB}

K nesporným výhodám dřevostaveb, oproti běžné zděné výstavbě, patří především rychlost samotné výstavby. Ta je dána mírou prefabrikace jednotlivých komponentů i omezením mokrých technologických procesů. $\mathrm{K}$ dalším výhodám patří dobré tepelně technické vlastnosti obvodových stěn, které si zachovávají subtilnost. Právě subtilní konstrukce vede k výhodnějšímu poměru užitné plochy k zastavěné ploše. Naopak k diskutovaným vlastnostem dřevostaveb patří nižší schopnost akumulace tepla a akustické vlastnosti vodorovných i svislých dělicích konstrukcí. [2]

Dřevostavby zároveň splňují některé aspekty udržitelné výstavby, jako jsou použití obnovitelného materiálu, nízké produkce $\mathrm{CO}_{2}$ a obecně nižší produkce odpadu v průběhu stavby oproti betonovým a ocelovým konstrukcím [8], [9].

Z hlediska dalšího vývoje výstavby dřevostaveb autoři neočekávají její pokles, také s ohledem na evropskou legislativu, především Nařízení Evropského parlamentu a Rady EU č. 305/2011. Toto nařízení mimo jiné uvádí, že „stavba musí být navržena, provedena a zbourána takovým způsobem, aby bylo zajištěno udržitelné použití přirodnich zdrojů a zejména: recyklovatelnost staveb, použitých materiálů a částí po zbourání, trvanlivost/životnost staveb, použití surovin a druhotných materiálů šetrných $k$ životnímu prostředi při stavběc. [10]

\section{OCEŇOVÁNÍ DŘEVOSTAVEB}

Rostoucí výstavba dřevostaveb je také velmi úzce spojena s obchodováním tohoto segmentu trhu. Zároveň se tak zvyšuje potřeba oceňovat dřevostavby, a to v různých fázích životního cyklu stavby. Životní cyklus stavby lze definovat jako časové období od vzniku myšlenky na stavbu až po její likvidaci. [11] S průběhem životního cyklu stavby je spjata potřeba určit hodnotu stavby v průběhu jednotlivých fází životního cyklu. Tím lze definovat různé situace, kdy se znalec může setkat s oceněním tohoto typu nemovitosti.

V prvotní fázi životního cyklu stavby jsou sledovány pořizovací náklady. Oceňuje se stavba jako taková, bez vlivu lokality a pozemku. V provozní fázi, tedy nejdéle trvající fázi životního cyklu stavby, je třeba nejčastěji určit tržní hodnotu, resp. cenu obvyklou. Ta je oproti předchozí fázi silně ovlivněna lokalitou, kde se předmětná stavba nachází a také faktem, že ocenění je běžně prováděno spolu s pozemkem, $\mathrm{k}$ němuž stavba náleží. $\mathrm{V}$ případě odhadu tržní hodnoty závěrečné fáze životního cyklu stavby - před demolicí, je vhodné přihlédnout i k nákladům na odstranění stavby.

Zaměřme se na nejdéle trvající fázi životního cyklu - provozní fázi. V této fázi se znalci a odhadci nejčastěji setkají se stanovením obvyklé ceny, resp. tržní hodnoty.

Zákon č. 151/1997 Sb., o oceňování majetku, v § 2 odst. 1 uvádí „Obvyklá cena vyjadřuje hodnotu věci a urči se porovnáním." [12] Odhadce se při aplikaci komparativního způsobu ocenění dřevostavby rodinného domu, který je v provozní fázi setkává hned s několika problémy. Pro správnou aplikaci komparativní metody ocenění je nutné nejdřive provést analýzu daného segmentu trhu.

Dřevostavby, rodinné domy na bázi dřeva, však provází nízká obchodovatelnost, což potvrzuje také mikroekonomický výzkum, který mapuje vývoj nabídkových cen po dobu trvání nabídky až po uskutečnění transakce u rodinných domů na území okresu Brno - venkov v Jihomoravském kraji. V rámci tohoto výzkumu jsou od 12. 3. 2017 kontinuálně shromažd'ovány inzerované nabídky všech rodinných domů ve výše zmíněném okrese. Ke všem nabídkám jsou poté dohledávány identifikační údaje z katastru nemovitostí. Nabídky, ke kterým byly tyto informace dohledány, jsou sledovány až po fázi uskutečnění transakce. Informace o prodejních cenách jsou poté získávány z katastru nemovitostí.

Jako indikátor efektivity trhu - prodejnosti nemovitých věcí, lze považovat dobu trvání nabídky T a především koeficient redukce na zdroj ceny $\mathrm{k}_{\mathrm{cz}}$. [15] Tento koeficient vyjadřuje poměr mezi prodejní (tržní) cenou a iniciační nabídkovou cenou. Hodnoty, které byly zjištěny v rámci mikroekonomického výzkumu, jsou uvedeny v tab. 2.

Tab. 1 Metody ocenění dle fáze životniho cyklu. Tab. 1 Approach to life cycle valuation.

\begin{tabular}{llll}
\hline & & \multicolumn{2}{c}{ Životní cyklus stavby } \\
\hline Fáze životního cyklu & Předinvestiční a investiční fáze & Provozní fáze & Likvidace \\
\hline Oceňovací př́stup & Nákladová metoda & $\begin{array}{l}\text { Porovnávací metoda + podpůrné metody } \\
\text { (Nákladová, Výnosová) }\end{array}$ & $\begin{array}{l}\text { Porovnávací metoda }+ \\
\text { nákladová metoda }\end{array}$ \\
\hline Výstup ocenění & Pořizovací náklady & Tržní hodnota/Cena obvyklá & $\begin{array}{l}\text { TH pozemku, Náklady } \\
\text { na odstranění }\end{array}$ \\
\hline
\end{tabular}

Tab. 2 Analýza trhu s drevostavbami.

Tab. 2 Analysis of the timber houses market.

\begin{tabular}{lcccccc}
\hline Mat. báze & \multicolumn{2}{c}{ Pozorování } & \multicolumn{2}{c}{$\mathbf{K}_{\mathrm{cz}}$} & \multicolumn{1}{c}{ T } \\
\hline & Vzorky celkem & Prodané & Průměr & Směrodatná odchylka & Průměr & Směrodatná odchylka \\
\hline Celkem & \multicolumn{7}{c}{ Rodinné domy - Brno-venkov } & & \\
Dřevostavby & 2790 & 301 & 0,89 & 0,13 & 171 & 99,8 \\
\hline
\end{tabular}


Procentuálně se tedy nabízí 3,83 \% dřevostaveb, přičemž ze 107 nabízených vzorků se u 81 nabídek jednalo o výstavbu dřevostaveb (stavba domu na klíč v některých př́padech i bez uvedení ceny pozemku) a pouze 26 nabídek bylo tvořeno již dokončenými dřevostavbami.

Prodané dřevostavby jsou zastoupeny pouze $1 \%$, je nutné podotknout, že prodané dřevostavby neobsahují stavby na „klíč” ani developerské projekty.

Dalším předpokladem pro úspěšné ocenění dřevostavby na základě porovnávacího způsobu ocenění je sestavení databáze. V ideálním případě je databáze srovnávacích nemovitostí pro komparativní př́stup ocenění sestavena $\mathrm{z}$ totožných entit, tedy dřevostaveb. Vzhledem k nízkému procentuálnímu zastoupení dřevostaveb na trhu s nemovitostmi to však může být značný problém.

Je samozrejmě možné sestavit srovnávací databázi zděných staveb, poté je pak vhodné, aby odhadce stanovil rozdílný vliv konstrukčního typu stavby na výsledný odhad ceny obvyklé. Autoři článku však doporučují využít jako podklad pro stanovení rozdílu konstrukčního systému stavby, procentuální rozdíl na základě tab. 3, pro stanovení koeficientu odlišnosti u komparativního př́stupu ocenění. Volba dalších koeficientů odlišnosti může být standardní jako u zděných rodinných domů. Vhodné je však zohlednit také energetickou náročnost dřevostavby a její energetický standard (pasivní, nízkoenergetický, nulový). U stanovení koeficientu redukce na pramen ceny je nutno provést analýzu segmentu daného trhu. Pro předmětnou lokalitu, období a typ nemovitostí mohou být použitelné dílčí výsledky mikroekonomického výzkumu.

Pokud není možné ocenit dřevostavbu porovnávacím způsobem, mezinárodní oceňovací standardy odkazují k použití náhradních metod pro stanovení tržní hodnoty.

Právě u staveb, které nejsou běžně obchodovány, nachází nákladová metoda své uplatnění v souladu s mezinárodními oceňovacími standardy. $\mathrm{V}$ těchto je pro oceňování budov a zařízení uvedeno: ,, Mnohé druhy budov a zařizení jsou však specializované a tam, kde nebudou u takovýchto položek k dispozici prímé doklady o prodeji, se musi při predkládáni názoru o hodnotě utvořeného na základě výnosového nebo nákladového prístupu postupovat s opatrností, jestliže jsou dostupni tržni údaje chabé nebo žádné. Za takových okolností může být namístě zvolit k ocenéní bud' výnosový prístup, nebo nákladový prístup. " [13]

$\mathrm{V}$ další kapitole mezinárodních oceňovacích standardů, konkrétně při oceňování práv k nemovitým věcem je u nákladového př́stupu v kapitole 70.3 uvedeno: „, Může být použit jako primárni prístup, pokud neexistují žádné doklady o transakčnich cenách za podobnou nemovitou věc ani žádný identifikovatelný skutečný nebo pomyslný výnosový tok dosahovaný vlastnikem príslušného majetkového práva. " [13]

\section{NÁKLADOVÁ METODA OCEŇOVÁNÍ DŘEVOSTAVEB}

Nákladová metoda oceňování se nejčastěji využívá pro zjištění výše pořizovacích nákladů stavby $\mathrm{v}$ předinvestiční a investiční fázi životního cyklu stavby. Současně může být použita jako metoda podpůrná, např́iklad u méně obchodovaných druhů staveb, rozestavěných staveb aj. Nákladovou metodu lze také využít pro stanovení reprodukční ceny při výnosovém způsobu ocenění, nachází tedy uplatnění i v provozní fázi životního cyklu stavby.

\subsection{Tradiční nákladový přístup}

K nejhojněji využívaným a nejrychlejším metodám odhadu pořizovacích nákladů staveb patří technicko-hospodářské ukazatele na účelovou měrnou jednotku. Tato metoda je však zatížena chybou ve výši $\pm 15 \%$. Např́íklad pro rodinné domy na bázi dřeva - dřevostavby je dostupný technicko-hospodářský ukazatel společnost RTS, s.r.o., pro rok 2019 ve výši $6240 \mathrm{Kč} / \mathrm{m}^{3}$, bez rozlišení počtu podlaží či znalosti konstrukčního systému stavby (obecně pro dřevostavby).

V konečném důsledku tak lze stanovit stejné pořizovací náklady pro roubenku i pro dřevostavbu ze sendvičového difúzně uzavřeného panelu.

Přesnější výši nákladů lze získat jen vyhotovením podrobného položkového rozpočtu. Zvláště na počátku předinvestiční fáze však nejsou potřebné podklady k dispozici. Stejně tak při využití nákladové metody jako náhradní metody znalec či odhadce nemá potřebné podklady k dispozici. Navíc zpracování podrobného položkového rozpočtu je nákladné.

\subsection{Alternativní nákladový přístup}

Jako alternativní př́stup $\mathrm{k}$ určení pořizovacích, resp. investičních nákladů, byly pro porovnání vlivu různých konstrukčních variant na pořizovací náklady použity nabídkové ceny na výstavbu rodinných domů na klíč. Tyto nabídkové ceny reprezentují náklady na pořízení rodinného domu, blížící se tržní hodnotě (samotné stavby bez vlivu pozemku). Pro investora pak představují investiční náklady.

Dalším důvodem pro použití nabídkových cen na výstavbu rodinných domů na klíč je také snazší dostupnost dat, což vede k sestavení databáze z dostatečného počtu vzorků a získání relevantních výsledků. Oproti využití rozpočtových ukazatelů či cenových soustav se jedná o ceny, za které je možno stavbu skutečně realizovat (jedná se o náklady s ohledem na trh), nebo vznikly na základě tržních principů. Nejedná se tak o využití uměle tvořených databází, které mohou výsledky zkreslovat.

Za účelem stanovení rozdílnosti pořizovacích, resp. investičních nákladů jednotlivých konstrukčních variant dřevostaveb byla sestavena databáze nabídkových cen na stavbu rodinných domů na klíč o celkovém počtu 175 vzorků.

Jednotlivé nabídky vždy obsahovaly stavbu jako celek včetně daně z přidané hodnoty, základové konstrukce na rovinatém pozemku, technologii vytápění a kompletní technické zařízení budov. Stejně tak jsou zahrnuty obklady, dlažby a podlahové krytiny. Zpravidla jsou v jednotlivých nabídkách zahrnuty levnější materiály pro povrchové úpravy tak, aby se nabízená cena př́liš nenavyšovala.

Z tab. 3 je patrný významný vliv konstrukční varianty rodinného domu na pořizovací náklady (resp. na nabídkovou cenu výstavby rodinného domu na klíč). Současně lze sledovat navýšení nabídkových cen u př́zemních rodinných domů o 9,7\% oproti vícepodlažním domům.

Z předchozích zkoumání také vychází, že výši nabídkové ceny na výstavbu rodinného domu na klíč ovlivňuje například tvar střechy (plochá vs. šikmá), způsob vytápění či propustnost konstrukce pro vodní páry (tedy volba difúzně uzavřené a otevřené 
Tab. 3 Vliv konstrukčnich variant staveb na nabidkové ceny rodinných domů na klíč v obdobi 2/2018. Tab. 3 Influence of construction variants on bid prices of houses in period 2/2018.

\begin{tabular}{|c|c|c|c|}
\hline \multirow{3}{*}{$\begin{array}{l}\text { Konstrukční varianta } \\
\text { CLT }\end{array}$} & \multicolumn{2}{|c|}{ Počet podlaží } & \multirow{3}{*}{$\begin{array}{c}\begin{array}{c}\text { Průměrná cena na } \mathbf{m}^{2} \\
\text { užitné plochy }\end{array} \\
30595 \mathrm{Kč}\end{array}$} \\
\hline & Přízemní & $31116 \mathrm{Kč}$ & \\
\hline & Vícepodlažní & $30074 \mathrm{Kč}$ & \\
\hline \multirow{2}{*}{ Roubenky a sruby } & Přízemní & $33445 \mathrm{Kč}$ & \multirow{2}{*}{$33001 \mathrm{Kč}$} \\
\hline & Vícepodlažní & $32557 \mathrm{Kč}$ & \\
\hline \multirow{2}{*}{ Sendvičový panel - difúzně OTEVŘENÁ skladba } & Přízemní & $29765 \mathrm{Kč}$ & \multirow{2}{*}{$28323 \mathrm{Kč}$} \\
\hline & Vícepodlažní & $26881 \mathrm{Kč}$ & \\
\hline \multirow{2}{*}{ Sendvičový panel - difúzně UZAVŘENÁ skladba } & Přízemní & $28188 \mathrm{Kč}$ & \multirow{2}{*}{$26285 \mathrm{Kč}$} \\
\hline & Vícepodlažní & $24382 \mathrm{Kč}$ & \\
\hline \multirow{2}{*}{ Staveništní montáž - difúzně OTEVŘENÁ skladba } & Přízemní & $28934 \mathrm{Kč}$ & \multirow{2}{*}{$26779 \mathrm{Kč}$} \\
\hline & Vícepodlažní & $24624 \mathrm{Kč}$ & \\
\hline \multirow{2}{*}{ Staveništní montáž - difúzně UZAVŘENÁ skladba } & Přízemní & $27480 \mathrm{Kč}$ & \multirow{2}{*}{ 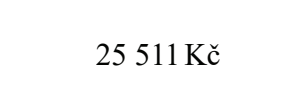 } \\
\hline & Vícepodlažní & $23542 \mathrm{Kč}$ & \\
\hline
\end{tabular}

konstrukce). Zároveň bylo potvrzeno, že velikost dodavatele stavby (resp. výše jeho ročních tržeb) neovlivňuje výši nabídkové ceny na výstavbu rodinného domu na klíč. [14]

\section{ZÁVĚR}

Rostoucí výstavba dřevostaveb přináší také zvýšenou četnost potřeby dřevostavby oceňovat, a to $\mathrm{v}$ různých fázích životního cyklu. Vyšší výstavbu dřevostaveb lze pozorovat v České republice až po roce 2000, postupně se také rozvíjí i trh s dřevostavbami samotnými.

Na základě provedeného porovnání lze konstatovat, že v př́ípadě využití nákladové metody se nelze spolehnout na obecné rozpočtové, resp. technickohospodářské ukazatele určené pro dřevostavby. Naopak je třeba věnovat pozornost konkrétnímu konstrukčnímu systému, který není v rozpočtovém ukazateli zohledněn.

Z porovnání nabídkových cen na výstavbu rodinných domů (resp. dřevostaveb) na klíč v různých konstrukčních variantách vyplývá, že právě druh použité konstrukce ovlivňuje výši nabídkové ceny konkrétní nemovité věci. Rozdíl jednotkových cen výstavby roubenky a běžné dřevostavby s difúzně uzavřenou konstrukcí může dosahovat až $7000 \mathrm{Kč} / \mathrm{m}^{2}$ užitné plochy, což je více než $22 \%$. Právě z toho lze usuzovat, že použití jednotného rozpočtového ukazatele pro všechny konstrukční systémy dřevostaveb je nevhodné.

Vzhledem k nízké obchodovatelnosti dřevostaveb, kterou potvrzuje realizovaný mikroekonomický výzkum, je při použití porovnávacího přístupu ocenění problém sestavení vhodné databáze, která by splňovala kvalitativní i kvantitativní požadavky kladené na sestavení srovnávací databáze. V ideálním př́ípadě je databáze srovnávacích nemovitostí pro rodinný dům sestavena z rodinných domů realizovaných ve stejném konstrukčním systému. Pro ocenění roubeného rodinného domu tak bude v ideálním př́padě sestavena ze srovnatelných roubených domů. Analogie pak platí i pro ostatní typy staveb. Při sestavení databáze ze zděných rodinných domů je vhodné, aby znalec či odhadce stanovil rozdílný vliv konstrukčního typu stavby na výsledný odhad ceny obvyklé. Autoři článku doporučuji využít jako podklad pro stanovení rozdílu konstrukčního systému stavby výsledky uvedené v tab. 3 . Doporučují také zohlednit energetickou náročnost dřevostavby, vybavení aj.

\section{Poděkování}

Tento př́spěvek vznikl v rámci projektu specifického výzkumu s názvem: „Oceñování nemovitostí: tržní a materiálové otázky současnosti“", ÚSI-J-18-5329.

\section{LITERATURA}

[1] TRANDOVÁ, L. Statistika výstavby dřevostaveb 2018 - počet nových drevostaveb $v \check{C} R$ neustále roste. Dřevo\&stavby[online]. 2019, 5.6.2019 [cit. 2019-07-30]. Dostupné z: https://www. drevoastavby.cz/drevostavby-archiv/doporucujeme/5515statistika-vystavby-drevostaveb-2018-pocet-novych-drevostavebv-cr-neustale-roste

[2] RŮŽIČKA, M. Moderni dřevostavba. Praha: Grada, 2014. ISBN 978-80-247-3298-5.

[3] PEŠTA, J. Rekonstrukce roubených staveb. Grada, Praha, 2013. ISBN 978-80-247-3239-8.

[4] Vyhláška č. 268/2009 Sb. k provedení stavebního zákona, ve znění pozdějších předpisů. In: ASPI [právní informační systém]. Praha: Wolters Kluwer ČR [vid. 2009-26-08].

[5] Vyhláška č. 78/2013 Sb. k provedení zákona o hospodaření energií, ve znění pozdějších předpisů. In: ASPI [právní informační systém]. Praha: Wolters Kluwer ČR [vid. 2013-29-03].

[6] PAVLAS, M. Dřevostavby z vrstvených masivnich panelu: technologie CLT. Grada Publishing, Praha, 2016. ISBN 978-80-271-0055-2. 
[7] VAVERKA, J. Dřevostavby pro bydlení. Grada, Praha, 2008. ISBN 978-80-247-2205-4.

[8] HUNG, Ch.-P., WEI, Ch., WANG, S. Y., LIN, F.-Ch. The study on the carbon dioxide sequestration by applying wooden structure on eco-technological and leisure facilities. Renewable Energy, 2009, 34(8), 1896-1901. DOI: https://doi.org/10.1016/j. renene.2008.12.015. ISSN 0960-1481.

[9] HU, Q., DEWANCKER, B., ZHANG, T., WONGBUMRU, T. Consumer Attitudes Towards Timber Frame Houses in China. Procedia - Social and Behavioral Sciences, 2016, 216, 841-849. DOI: https://doi.org/10.1016/j.sbspro.2015.12.081. ISSN $1877-0428$.

[10] ŠIMKOVÁ, A. Posuzováni stavebních výrobků: komentár̆ k nařizeni Evropského parlamentu a Rady (EU) č. 305/2011. Praha: Pro Českou komoru autorizovaných inženýrů a techniků činných ve výstavbě vydalo Informační centrum ČKAIT, 2011.
ISBN 978-80-87438-22-0.

[11] HAČKAJLOVÁ, L. Ekonomika a management 13. Vydavatelství ČVUT, Praha, 2004. ISBN 800-10-3060-1.

[12] Zákon č. 151/1997 Sb., o oceňování majetku, ve znění pozdějších předpisů. In: ASPI [právní informační systém]. Wolters Kluwer ČR, Praha [vid. 2009-26-08].

[13] Mezinárodní oceňovací standardy 2017. Jesenice: Ekopress, 2018. ISBN 978-80-87865-44-6.

[14] HRDLIČKA, T., CUPAL, M. Brick versus wood construction in residential building. In: $19^{\text {th }}$ International Multidisciplinary Scientific GeoConference SGEM 2019, Bulgaria, 2019, s. 395-402. ISBN 978-619-7408-89. ISSN 1314-2704.

[15] CUPAL, M. Bid prices and market prices relation of real estates modelling. Journal of International Scientific Publications: Economy \& Business, 2010(4), s. 213-220. ISSN 1313-2555.

\section{Správná citace:}

HRDLIČKA, T., JANDÁSKOVÁ, T. Oceňování dřevostaveb v kontextu tržního oceňování. Soudní inženýrství, 2019, 30(3), 23-28. DOI: http://dx.doi.org./10.13164/SI.2019.3.23. ISSN 1211-443X. 